\title{
Penerapan Sistem iLearning Raharja Ask And News (iRAN) Dalam Mendukung Media Informasi Kampus Pada Perguruan Tinggi Raharja
}

\author{
Untung Rahardja ${ }^{1}$ \\ Dina Fitria Murad ${ }^{2}$ \\ Bunga Pertiwi ${ }^{3}$ \\ e-mail : untung@raharja.info,dina.fitria@raharja.info,bunga@raharja.info
}

Diterima : 3 Desember 2013 / Disetujui: 11 Desember 2013

\begin{abstract}
Media information developed so rapidly in line with technological developments. Media information running on a college, greatly affects the student in understanding the developments taking place in its environment. Application of the media aims to facilitate students in meeting the needs of science. However, the use of the information media and the campus is not optimal yet computerized student ignorance will lead to the existence of such media. Thus the importance of online information media to facilitate the process of information retrieval. Now with iLearning learning, all the information can be integrated extensively. iRAN is a campus information media that have been computerized aims to manage all documentation of an event, incident, and campus information. In this case to measure the quality of information produced, iRAN adopted a study conducted by DeLone and McLean (1992) showed that among the six categories that build on the success of information systems, there is a connection and dependence which then determine the success or failure of the implementation of an information system. In addition there are 6 literature reviews that can be used as references in preparing this report. The final result of the study is an integrated information system that is widely campus, where iRAN can provide the latest information about activities or events that are taking place within the campus while also every student can participate share what they know into iRAN.
\end{abstract}

Keywords: information, online media information, iLearning, iRAN

1. . Dosen Jurusan Sistem Informasi, STMIK Raharja

Jl. Jend Sudirman No. 40 Modern Cikokol-Tangerang Telp. 5529692

2. . Dosen Jurusan Sistem Informasi, STMIK Raharja

Jl. Jend Sudirman No. 40 Modern Cikokol-Tangerang Telp. 5529692

3. - Mahasiswa Jurusan Sistem Informasi, STMIK Raharja

Jl. Jend Sudirman No. 40 Modern Cikokol-Tangerang Telp. 5529692 


\begin{abstract}
ABSTRAKSI
Media informasi berkembang begitu pesat seiring dengan perkembangan teknologi. Media informasi yang berjalan pada suatu perguruan tinggi, sangat mempengaruhi mahasiswa dalam memahami perkembangan yang terjadi di lingkungan sekitarnya. Penerapan media tersebut bertujuan untuk mempermudah mahasiswa dalam memenuhi kebutuhan akan ilmu pengetahuan. Namun penggunaan media informasi kampus yang belum optimal dan belum terkomputerisasi menyebabkan ketidaktahuan mahasiswa akan keberadaaan media tersebut. Sehingga pentingnya media informasi online untuk mempermudah dalam proses pencarian informasi. Kini dengan adanya pembelajaran iLearning, semua informasi dapat terintegrasi secara luas. iRAN merupakan media informasi kampus yang sudah terkomputerisasi bertujuan untuk mengelolah semua dokumentasi tentang suatu peristiwa, kejadian, serta informasi kampus. Dalam hal ini untuk mengukur suatu kualitas informasi yang dihasilkan, iRAN mengadopsi penelitian yang dilakukan oleh DeLone dan McLean (1992) yang menunjukkan bahwa diantara enam kategori yang membangun keberhasilan sistem informasi, terdapat suatu keterkaitan dan ketergantungan yang kemudian menentukan berhasil atau tidaknya penerapan suatu sistem informasi. Selain itu terdapat 6 literature review yang dapat dijadikan sebagai referensi dalam menyusun laporan ini. Hasil akhir dari penelitian adalah sebuah sistem informasi kampus yang terintegrasi secara luas, dimana iRAN dapat memberikan informasi terbaru mengenai kegiatan atau kejadian yang sedang berlangsung di lingkungan kampus selain itu juga setiap mahasiswa dapat berpatisipasi membagi informasi yang mereka ketahui melalui iRAN.
\end{abstract}

Kata kunci : informasi, media informasi online, iLearning, iRAN

\title{
PENDAHULUAN
}

Saat ini perkembangan teknologi informasi berkembang begitu pesat. Teknologi informasi berbasis komputer menjadi suatu kebutuhan utama bagi setiap orangdalam memenuhi kebutuhan informasi. Banyakbidang yangtelahmemanfaatkan perkembangan teknologi informasi sebagai sarana untuk mempermudah pekerjaan. Mulai dari kalangan pembisnis sampai dengan kalangan pendidik memanfaatkan komputer sebagai alat bantu untuk mempermudah pekerjaan mereka.

Teknologi informasi juga memiliki andil yang besar dalam hal sarana pembelajaran seperti yang kita ketahui bahwa teknologi informasi kini telah merasuk ke dalam kurikulum dunia pendidikan. Suatu hal yang tentunya menjadi gebrakan di dunia pendidikan dalam ajang peningkatan potensi belajar. Selain itu gelombang kemajuan dan perkembangan teknologi dalam bidang pendidikan telah membawa perubahan pada kehidupan dan gaya hidup pelajar yang lebih dinamis. Dengan adanya hal tersebut, maka pelajar senantiasa menghidupkan dan menyalurkan semangat untuk mengeksplorasi ilmu yang belum diketahui. 
Melihat pentingnya peranan teknologi tersebut, maka pendidikan yang menjadi tonggak awal dalam melahirkan manusia berkualitas, dituntut untuk senantiasa meningkatkan mutu pendidikan terutama dalam hal ilmu pengetahuan dan teknologi yang terus berkembang. Saat ini media informasi menjadi salah satu sarana yang diperlukan dalam meningkatkan pengetahuan. Dahulu orang memperoleh pengetahuan/informasi hanya melalui media cetak seperti koran, majalah dan tabloid. Penggunaan kertas dalam media cetak akan mengakibat kenaikan suhu di permukaan bumi karena penebangan pohon secara terus-menerus yang nantinya membawa dampak buruk bagi bumi. Selain itu penggunaan media cetak kurang efesien karena membutuhkan waktu yang lama untuk mencetaknya. Maka untuk mengatasi permasalahan tersebut dibutuhkan media informasi berbasis komputer yang praktis, cepat dan akurat.

Media informasi di suatu perguruan tinggi digunakan sebagai sarana untuk memperoleh informasi yang ada di lingkungan kampusnya seperti informasi seputar kampus yang berisi peristiwa, kegiatan atau kejadian yang sedang berlangsung saat ini. Media adalah alat bantu apa saja yang dapat dijadikan sebagai penyalur pesan guna mencapai tujuan pembelajaran” (Djamarah, 1995:136). Dengan adanya media tersebut segala informasi dapat terpublikasikan dengan baik sehingga mahasiswa dapat mengetahui seluruh kegiatan kampus. Media informasi secara tidak langsung telah mempengaruhi budaya dan cara pendidikan di lingkungan masyarakat. Media informasi yang disajikan harus bermanfaat bagi pembacanya dan informasi yang ditampilkan harus akurat, cepat dan relevan.

Namun dalam kenyataannya hal tersebut tidak sesuai dengan keinginan dan harapan yang hendak dicapai, dikarenakan keterbatasan sistem atau perangkat informasi yang digunakan. Saat ini media informasi yang berjalan pada Perguruan Tinggi belum berkembang secara luas. Beberapa permasalahan yang menghambat media informasi tersebut yaitu kurangnya sosialisasi terhadap media informasi di lingkungan kampus sehingga banyak yang tidak mengetahui keberadaan media informasi tersebut, selain itu kurangnya minat membaca di kalangan mahasiswa pun menjadi permasalahan tersendiri yang harus segera diatasi.

Oleh karena itu sebagai salah satu perguruan tinggi yang bergerak di bidang komputer. Harus selalu berinovasi untuk meningkatkan kualitas pembelajaran. Salah satunya dengan menerapkan sistem pembelajaran iLearning. Pada dasarnya istilah iLearning (Integrated Learning) berasal dari pemikiran perkembangan teknologi iPad di Perguruan Tinggi Raharja. Belajar, bermain, berdoa dan bekerja merupakan konsep pembelajaran yang dimiliki oleh iLearning. Pembelajaran yang secara efisien, praktis dan menyenangkan sehingga membuat mahasiswa menjadi lebih attractive dan semangat dalam belajar dengan didukung teknologi yang mempermudah 
jangkauan mahasiswa dalam melakukan interaksi. Berdasarkan tulisan mengemukakan bahwa iLearning adalah sistem pembelajaran modern dan terbaru dalam dunia pendidikan yang berbasis 4B (Belajar, Bekerja, Bermain, dan Berdoa) dan dapat di implementasikan sebagai infrastruktur 4B iLearning (Untung Rahardja, 2011), seperti pada gambar berikut ini :

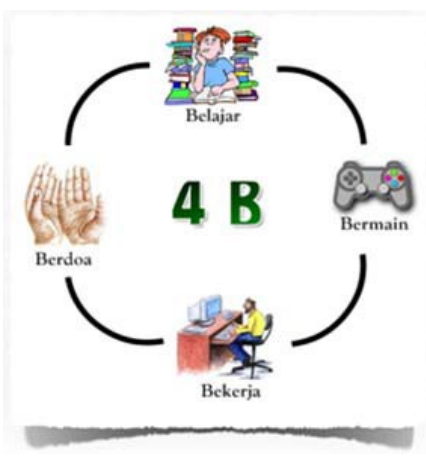

\section{Gambar 1. Infrastruktur 4B iLearning}

Sistem pembelajaran iLearning yang diterapkan di suatu Perguruan Tinggi harus saling berhubungan dan berkaitan satu sama lain. iLearning merupakan inovasi baru dalam dunia pendidikan yang memanfaatkan perkembangan teknologi informasi. Kini dengan adanya metode pembelajaran iLearning, terciptalah terobosan-terobosan baru yang dapat mempermudah mahasiswa dalam mendapatkan pelayanan dan informasi seputar kampus. Contohnya media informasi kampus yang sebelumnya tidak dikenal secara luas kini dengan adanya iLearning, media informasi kampus dapat terintegrasi secara luas dan dapat dikenal oleh mahasiswa Perguruan Tinggi Raharja. Selain itu dengan tampilan berita yang mudah diharapkan dapat menarik minatmembacamahasiswa.

\section{PERMASALAHAN}

Media informasi diperlukan sebagai wadah yang dapat menampung segala bentuk informasi. Peranan media tersebut sangat penting bagi dokumentasi terhadap kegiatan yang sedang berlangsung serta bisa digunakan sebagai pengarsipan atas informasi yang dibutuhkan. Suatu perguruan tinggi harus bisa menampung semua publikasi kegiatan kampus melalui suatu website online. Tujuannya agar mahasiswa dapatmengetahui informasi seputar kampus. Namun saat ini, media yang digunakan 
belum terkomputerisasi dan belum online. Sehingga masih menggunakan media konvensional seperti kertas, spanduk, pamflet, stand banner serta majalah dinding (mading). Hal tersebut membuat informasi yang dipublikasikan kurang efektif dan efesien. Untuk penjabaran yang lebih rinci perihal permasalahan dari media informasi dapat dilihat pada Mind Mapping. Seperti tampak pada gambar dibawah ini :

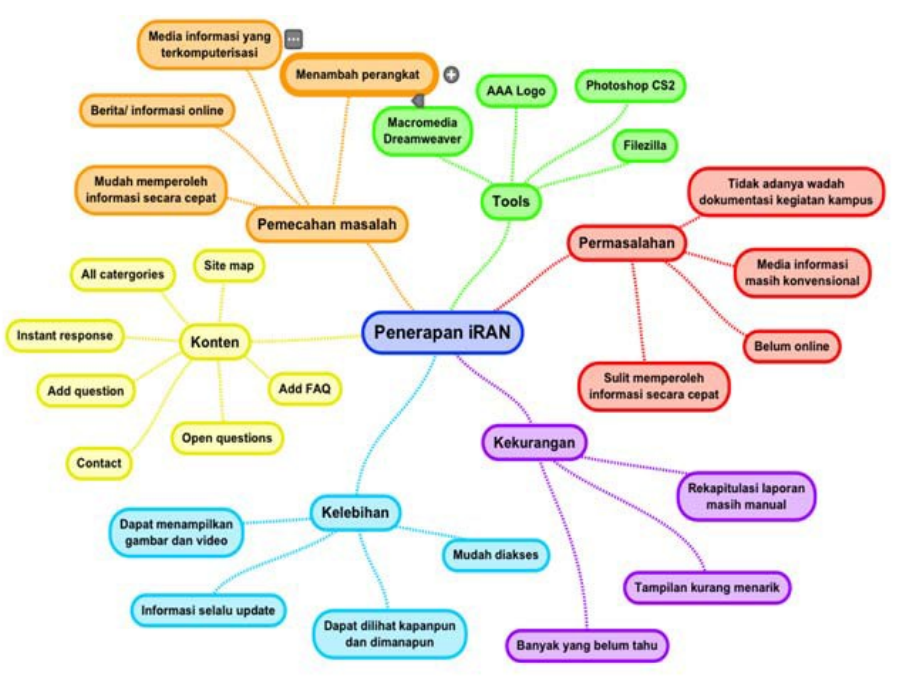

\section{Gambar 2. Mind mapping permasalahan media informasi}

Di dalam Mind Mapping terdapat 4 (empat) permasalahan yang ada pada media informasi tersebut, yaitu permasalahan pertama adalah sulitnya memperoleh informasi secara cepat. Permasalahan kedua adalah belum adanya media online. Permasalahan ketiga yaitu tidak tersedianya wadah yang menampung arsip dokumentasi kegiatan kampus dan permasalahan keempat adalah media informasi yang digunakan masih konvensional.

Penjabaran dari permasalahan pertama tentang sulitnya memperoleh informasi secara cepat, dalam permasalahan ini mahasiswa yang ingin mendapatkan informasi yang dibutuhkan harus mencari pihak yang bersangkutan untuk memperoleh informasi sehingga terasa sulit memperoleh informasi. Kemudian permasalahan kedua mengenai belum adanya media online, pentingnya informasi dipublikasikan melalui media online agar mempermudah mahasiswa dalam hal proses pencarian data dan informasi kalau tidak dilakukan secara online mahasiswa akan bingung harus mencari informasi dimana dan kepada siapa. Selain itu pada permasalahan ketiga, informasi yang ada tidak dikumpulkan di suatu wadah akan mengakibatkan tercecernya berbagai 
informasi penting. Permasalahan yang keempat mengenai penggunaan media konvesional seperti kertas, pamflet, spanduk serta mading dalam penyampaian informasi. Contohnya seperti surat edaran yang biasanya digunakan untuk memberitahukan kepada mahasiswa tentang batas akhir pembayaran registrasi serta total biaya yang harus dibayarkan. Surat tersebut biasanya dikirimkan ke masingmasing alamat rumah mahasiswa namun karena alamat data mahasiswa yang tidak lengkap menyebabkan sebagian surat tidak terkirim ke alamat yang dituju. Sehingga kurang efektif jika hal tersebut secara terus menerus dilakukan, lagipula penggunaan kertas dapat meningkatkan kenaikan suhu di permukaan bumi karena penebangan pohon yang terus menerus untuk memenuhi persediaan bahan baku kertas. Media selain surat edaran yaitu mading, namun untuk membaca informasi yang tersedia di mading mahasiswa terkadang malas untuk membacanya di samping itu informasi yang ditempel di mading tidak update karena informasi yang lama masih di tempel di mading. Dan contoh-contoh media informasi yang lain seperti pamflet, spanduk dan stand bannner tidak ekonomis karena harus mengeluarkan uang dalam jumlah tidak sedikit untuk mencetaknya.

\section{LITERATURE REVIEW}

Banyak penelitian yang sebelumnya telah dilakukan mengenai media ask and news. Dalam upaya mengembangkan media ask and news perlu adanya studi pustaka sebagai salah satu penerapan metode penelitian. Diantaranya adalah mengidentifikasikan kesenjangan (identify gaps), menghindari pembuatan ulang (reinventing the wheel), mengidentifikasikan metode yang pernah dilakukan, serta mengetahui orang lain yang spesialisasi dan area penelitian yang sama dibidang ini. Beberapa Literature review tersebut adalah sebagai berikut :

1 Penelitian yang di lakukan oleh Fahme Dabaj dan Agah Gumus dengan judul “The Mathematical Relationship Between The Lead And Body Lenghts, And The Degree Of Satisfation Attained From The Both Sections Of The News Articles Published In Newspapers: Case Study;Tuskish Daily Online Newspapers" menjelaskan bahwa untuk mempelajari hubungan antara kalimat utama dan tubuh dalam artikel surat kabar mempertimbangkan kepuasan pembaca kemudian formulizing ke dalam persamaan matematika. Dalam studi tersebut, harian koran online Turki hanya digunakan untuk mengukur tingkat kepuasan pembaca dicapai oleh memimpin dan bagian tubuh dari artikel di koran online, mengingat panjangnya. Setelah menerapkan metode statistik, 
korelasi dan regresi, untuk temuan, penelitian menunjukkan bahwa kepuasan pembaca bisa diukur, bahwa rumus-rumus matematika tertentu dapat diturunkan dari pada panjang tubuh dengan menggunakan panjang memimpin, dan dari atasnya, menggunakan kedua tubuh dan memimpin panjang, kita dapat memformulasikan atasnya pembaca-kepuasan.

I2 Penelitian yang dilakukan oleh Padmini Patwardhan dan Jin Yang dengan judul "Internet Dependency Relations And Online Consumer Behavior: A Media System Depedency Theory Perspective On Why People Shop, Chat And Read News Online” Pada penelitian ini, memperkenalkan Hubungan Ketergantungan Internet (IDR) sebagai prediktor kegiatan konsumen online. Rp didasarkan pada perspektif teoritis dari teori Ketergantungan Sistem Media, yang mendalilkan hubungan ketergantungan antara individu dan media berdasarkan kegunaan yang dirasakan dari media dalam pemahaman pertemuan (sosial / diri), orientasi (tindakan / interaksi) dan bermain (sosial / soliter) gol. Menggunakan survei cross-sectional email dari 166 responden secara acak diambil dari fakultas, staf, dan populasi mahasiswa di sebuah universitas pertengahan barat besar di Amerika Serikat, pengaruh prediksi IDR on belanja online, chatting, dan membaca berita itu diuji secara empiris . Rata-rata, konsumen dalam survei telah membeli delapan produk online dalam enam bulan terakhir, menghabiskan dua puluh satu menit setiap hari membaca berita online pada harian media regional, dan mengobrol sepuluh menit setiap hari di Internet. Mereka juga ditampilkan moderat, meskipun hubungan ketergantungan positif dengan Internet. Rp signifikan menjelaskan kegiatan belanja online dan membaca berita online, tapi tidak memprediksi online chatting. Dari segi dimensi tujuan Rp spesifik, pengaruh prediksi orientasi tindakan pada online, belanja bermain soliter di chatting online, dan pemahaman sosial pada membaca berita online dikonfirmasi.

3 Penelitian yang dilakukan oleh Klaus Schonbach, Ester De Waal dan Edmund Lauf yang berjudul "Online And Print Newspapers: Their Impact On The Extent Of The Perceived Public Agenda” menjelaskan bahwa Cara koran cetak yang terstruktur dan digunakan seharusnya untuk memikat pembaca membaca cerita ke mereka mungkin belum tertarik sebelumnya. Makalah online mendukung aktivitas dan kontrol oleh pengguna, mereka menyadari berbagai sempit topik sesuai dengan individu seseorang kepentingan yang lebih masuk akal. Sebuah survei wakil dari hampir 1000 responden menunjukkan itu lebih rumit dari itu. Kedua saluran sebenarnya berkontribusi untuk memperluas agenda penonton. Namun, sementara surat kabar online menunjukkan efek ini hanya pada kelompok berpendidikan tertinggi 
masyarakat, cetak surat kabar dapat memperluas cakrawala mereka yang berbagai kepentingan berada pada rata-rata paling.

4 Penelitian yang dilakukan oleh Mark Deuze yang berjudul “The Web and Its Journalisms: Considering The Consequences Of Different Types Of Newsmedia Online” menjelaskan perihal Internet - khususnya antarmuka grafis, dunia wide web - memiliki dampak besarpada semua tingkat(informasi) masyarakat di seluruh dunia. secara khusus untuk jurnalisme seperti yang dipraktekkan online, kami sekarang dapat mengidentifikasi pengaruh yang dimiliki hal ini terhadap profesi dan nya budaya (s). Artikel ini mendefinisikan empat jenis tertentu secara online jurnalisme dan membahasnya dalam hal kunci karakteristik penerbitan online - hypertextuality, interaktivitas, multimediality - dan menganggap arus dan potensi dampak bahwa journalisms bisa online memiliki pada cara di mana orang dapat mendefinisikan jurnalistik sebagai itu berfungsi dalam demokrasi elektif di seluruh dunia. hal ini berpendapat bahwa penerapan online tertentu karakteristik tidak hanya memiliki konsekuensi untuk jenis jurnalisme diproduksi di web, tetapi bahwa karakteristik dan journalisms online memang terhubung ke lebih luas dan lebih mendalam perubahan dan redefinitions dari profesional jurnalisme dan (berita) budaya secara keseluruhan.

5 Penelitian ini dilakukan oleh Untung Rahardja, Muhamad Yusup dan Eva Rosyifa dari Perguruan Tinggi Raharja tahun 2012 yang berjudul "Perancangan Aplikasi iLearning Majalah Online Dengan Menggunakan iOS Programming Pada Perguruan Tinggi”. Penelitian ini membahas sifat publikasi penyampaian informasi bersifat penting karena dapat membantu dan melakukan pencarian akan informasi yang sebelumnya tidak diketahui. Serta media publikasi masih berkaitan satu sama lain sehingga kebutuhan akan informasi sifatnya masih sangat tinggi dan dari sebagian tempat sifatnya masih sangat rendah dan proses pengupdatean akan informasi masih bersifat minim. Sehingga diharuskan melakukan perancangan aplikasi iLearningmajalahonlinedengan menggunakan iOS Programming, yang diharapkan bisa di akses melalui iPhone dan iPad yang bisa di download melalui iTunes demi meningkatkan peran media dalam perguruan tinggi supaya jauh lebih baik dan tentunya bermanfaat.

6 Penelitian yang dilakukan oleh DeLone \& McLean tahun 1992. Penelitan tersebut mengembangkan suatu model parsimoni yang mereka sebut dengan nama model kesuksesan sistem informasi DeLone \& McLean (D\&M Information System Success Model). Model yang diusulkan ini merefleksi ketergantungan dari enam pengukuran kesuksesan sistem informasi. Keenam elemen atau faktor atau komponen atau pengukuran dari model ini. Model 
kesuksesan ini didasarkan pada proses dan hubungan kausal dari dimensidimensi di model. Model ini tidak mengukur ke enam dimensi pengukuran kesuksesan sistem informasi secara independen tetapi mengukurnya secara keseluruhan satu mempengaruhi yanglainnya.

Dari enam literature review yang ada, telah banyak penelitian mengenai media informasi online. Di samping itu juga ada pembahasan mengenai iLearning. Namun dapat disimpulkan bahwa belum ada peneliti yang secara khusus membahas mengenai perancangan media informasi kampus yang digunakan sebagai media penyimpanan dokumentasi kegiatan kampus.

\section{METODE PENELITIAN}

Dalam melakukan penelitian terhadap media informasi kampus dibutuhkan suatu metode penelitian yang mampu memberi gambaran terhadap tingkat kualitas suatu sistem informasi. Berdasarkan kebutuhan tersebut, peneliti mencoba menganalisa sebuah teori model kesuksesan sistem informasi yang diterapkan dan dikembangkan oleh DeLone and McLean (1992). Penelitian tersebut mengembangkan suatu model parsimoni yang mereka sebut dengan nama model kesuksesan sistem informasi DeLone \& McLean (D\&M Information System Success Model). Model kesuksesan ini didasarkan pada proses dan hubungan kausal dari dimensi-dimensi di model. Model ini tidak mengukur keenam dimensi pengukuran kesuksesan sistem informasi secara independen tetapi mengukurnya secara keseluruhan, satu mempengaruhi yang lainnya. Seperti pada gambar berikut:

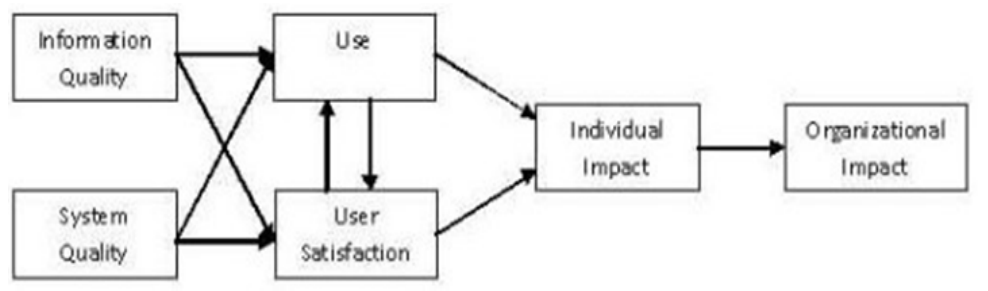

Gambar 3. Model DeLone \& McLean (1992)

Model yang diusulkan ini merefleksi ketergantungan dari enam pengukuran kesuksesan sistem informasi. Keenam elemen atau faktor atau komponen atau pengukuran dari model ini adalah kualitas system (system quality), kualitas informasi (information quality), penggunaan (use), kepuasan pemakai (usersatisfaction), 
dampak individual (individual impact) dan dampak organisasional (organizational impact).

Dari metode penelitian menurut DeLone and McLean, media informasi yang berkualitas tergantung dari sistem, informasi, dan pelayanan yang dihasilkan. Selain itu kualitas sistem, informasi dan pelayanan akan mempengaruhi penggunaan serta kepuasan pemakai yang nantinya akan berdampak bagi individu serta organisasi itu sendiri. Berdasarkan penjelasan dari komponen pendukung tersebut, maka penulis mencoba merancang suatu media informasi kampus yang dapat memberikan pelayanan yang berkualitas dibandingkan dengan media yang saat ini sedang berjalan masih konvensional. Dengan adanya sistem yang mampu menampung informasi akan memberikan pelayanan informasi yang maksimal. Kualitas informasi yang dihasilkan akan lebih baik karena semua tercatat secara komputerisasi dan dapat diakses secara online.

\section{PEMECAHAN MASALAH}

Dengan melihat permasalahan yang terjadi maka perlu adanya media online yang mampu menyajikan informasi secara terpusat untuk memudahkan mahasiswa dalam proses pencarian informasi yang dibutuhkan. Berdasarkan permasalahan yang telah dijabarkan, penulis mencoba menjawab semua permasalahan dengan merancang sebuah aplikasi sistem iLearning Raharja Ask and News (iRAN). Aplikasi yang meyajikan informasi berupa artikel, peristiwa serta kejadian yang berupa news. Semua artikel dan news yang tersimpan merupakan lingkup seputar kampus Perguruan Tinggi Raharja. News adalah suatu pekerjaan yang berhubungan dengan kegiatan mencari, meliput, mendokumentasikan serta merangkai bahasa menjadi bahasa formal hingga menjadikan sebuah berita.

iRan mengolah data dokumentasi kegiatan kampus secara terkomputerisasi dengan suatu media digital hingga menghasilkan informasi yang mudah diakses mahasiswa. Selain itu, dengan informasi yang terpusat dapat memudahkan dalam pengarsipan dokumentasi kampus, berita yang sudah terkomputerisasi dan online dapat di lihat dimanapun dan kapanpun oleh mahasiswa sehingga mereka tidak harus datang kekampus untuk memperoleh informasi atau kejadian apa yang sedang berlangsung di kampus karena sudah ada media informasi online yang mampu menyanjikan informasi tersebut. iRAN merupakan salah satu dari 10 pilar IT iLearning yang terhubung satu dengan lainnya. Seperti pada gambar berikut ini : 


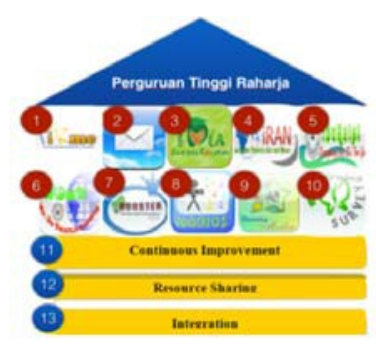

Gambar 4. Pilar IT iLearning

Aplikasi iRAN memuat seluruh tutorial/ informasi mengenai 10 Pilar IT iLearning, oleh karena itu disebut berkaitan. Kelebihan dari iRAN yaitu dapat menampilkan beberapa konten yang dapat diakses secara bebas oleh mahasiswa. Sehingga kita dapatmelihat letak kebutuhaninformasi yang diperlukan. Sesuai dengan teori menurut DeLone and McLean (1992) yang mengatakan bahwa salah satu faktor yang dapat menentukan keberhasilan dari sistem informasi adalah kualitas dari sistem. Jika sistem yang di terapkan mampu memberikan pelayanan serta informasi yang bermanfaat bagi pengguna maka kualitas dari sistem informasi akan meningkat. Hal tersebut juga akan berdampak baik terhadap pelayanan informasi di lingkungan kampus. Untuk menggambarkan flowchart alur program yang berjalan saat ini dari sistem iRAN maka penulis menggambarkannya sebagai berikut:

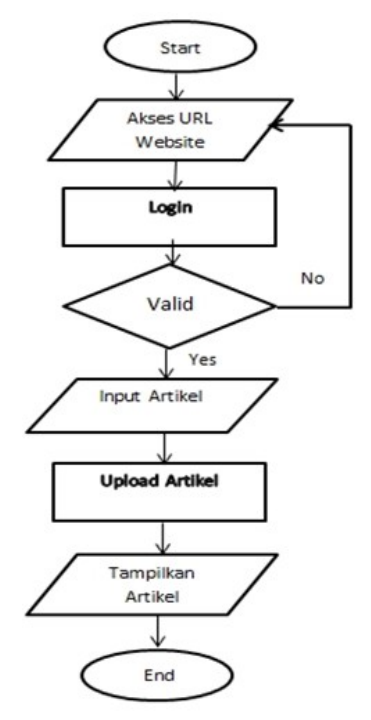

Gambar 5. Flowchart Pembuatan Artikel di iRAN 
Flowchart diatas merupakan salah satu alur dari proses penulisan artikel di iRAN. Alur flowchart menjelaskan bahwa untuk membuat artikel sampai dengan proses upload, kita harus melakukan login terlebih dahulu, setelah itu jika account login dinyatakan valid maka sistem mengeksekusi proses selanjutnya dengan menampilkan kolom input artikel sampai proses upload berhasil. Untuk melihat peranan dari komponen yang terlibat di dalam sistem iRAN, penulis membuat suatu rancangan usulan sistem. Dapat dilihat pada gambar use case dibawah ini :

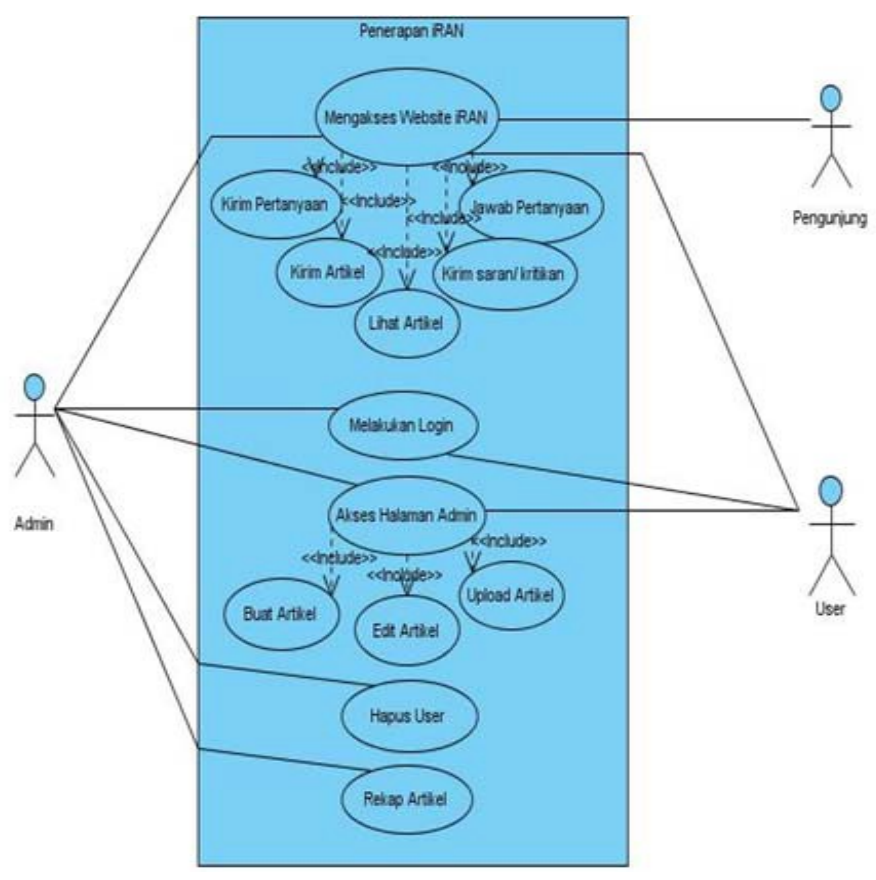

Gambar 6. Use Case Diagram

Use case pada dasarnya merupakan gambaran dari proses sistem secara keseluruhan yang melibatkan actor dalam hal penggunaan. Dalam use case diagram ini terdapat 3 actor yang terlibat didalam sistem iRAN, dimana masing-masing actor memiliki hak akses yang berbeda. Pengunjung memiliki hak akses melihat konten yang terdapat didalam iRAN seperti mengirim artikel seputar kampus, mengirim pertanyaan tentang informasi yang belum tersedia, menjawab pertanyaan, mengirimkan kritikan/ saran tentang pelayanan yang disajikan dan melihat semua kategori artikel yang tersimpan didalam iRAN. Untuk memiliki account login, pengunjung dapat 
melakukan registrasi terlebih dahulu. Setelah memiliki account login, pengunjung tersebut berganti status menjadi user. User bisa masuk kedalam menu admin. Menu admin memuat beberapa fasilitas seperti approve langsung artikel yang ditulis, dapat melihat statistik pengunjung, jumlah artikel yang tersimpan, dan lain sebagainya. Namun untuk menghapus artikel, menghapus user dan rekap artikel hanya dapat dilakukan oleh admin. Berikut ini merupakan activity diagram dari sistem iLearning Raharja Ask and News (iRAN) :

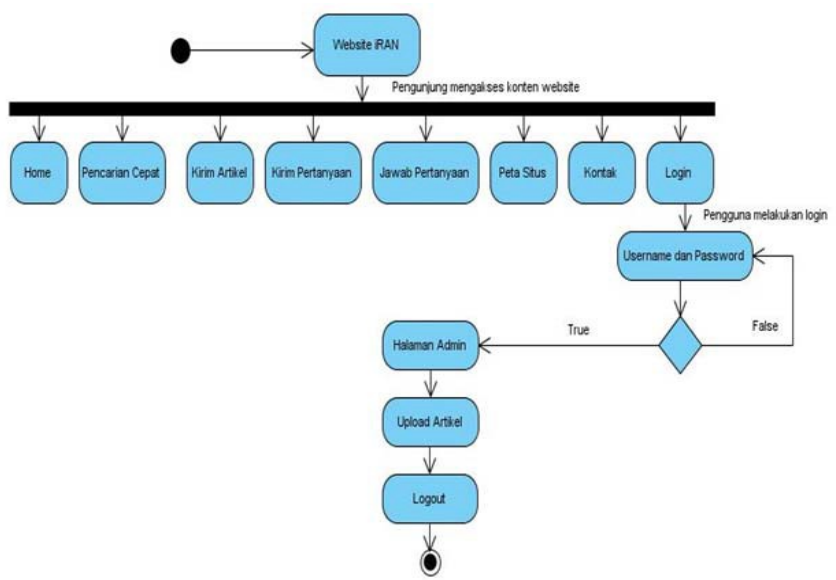

Gambar 7. Activity Diagram

Dengan adanya activity diagram diatas sedikit menjelaskan bahwa aktifitas dari program berjalan seperti apa, sama halnya dengan flowchart sebelumnya. Di dalam activity diagram ini menjelaskan salah satu aktifitas user dalam melakukan proses upload artikel.

Sistem iLearning Raharja Ask and News (iRAN) sebagai media informasi harus mempunyai kualitas yang baik. Karena informasi dapat diibaratkan sebagai darah yang mengalir didalam tubuh manusia, seperrti halnya informasi didalam sebuah perguruan tinggi yang sangat penting untuk mendukung kelangsungan perkembangannya, sehingga terdapat alasan bahwa informasi sangat dibutuhkan bagi sebuah perguruan tinggi. Akibat bila kurang mendapatkan informasi dalam waktu tertentu perguruan tinggi akan mengalami kesulitan untuk mengontrol sumber dayanya, sehingga dalam mengambil keputusan-keputusan strategis, sangat terganggu yang pada akhirnya akan mengalami kekalahan dalam persaingan dengan lingkungan pesaingnya. 


\section{Listing Program}

Dibawah ini merupakan view detail listing program iLearning Raharja Ask and News Pada Perguruan Tinggi Raharja, yaitu sebuah script dari proses login. Berikutlisting programnya

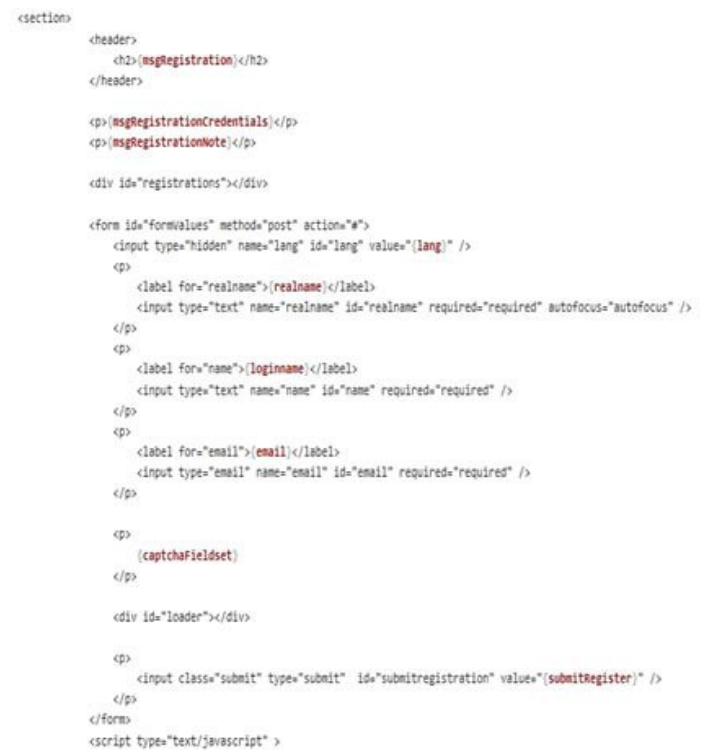

\section{IMPLEMENTASI}

A. Tampilan Prototype

Adanya perancangan prototype antar muka ini dibuat agar pengguna (user) diberikan kemudahan dalam perekayasaan pembuatan aplikasi program. Adapun bentuk prototype sistem iLearning Raharja Ask and News (iRAN) yang diusulkan merupakan desain dialog pengguna untuk masing-masing proses dalam sistem informasi yang dibangun berikut sebagian Perancangan prototype sistem usulan (Prototype) selengkapnya ada pada lampiran dibawah ini :

\section{Prototype Logo iRAN}

Pada prototype ini kita dapat melihat desain prototype logo iRAN. Didalam logo iRAN terdapat filosofi yang menggambarkan keterkaitan sistem iRAN dengan 
Perguruan Tinggi Raharja. Setiap warna yang terkandung memiliki fiosofi yang berbeda.

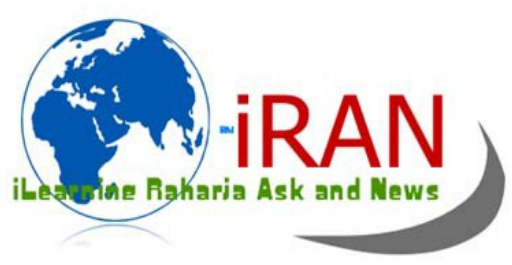

Gambar 8. Logo iRAN

2. Tampilan Menu Home (Semua kategori)

Menu home merupakan tampilan awal yang pertama kali akan muncul saat usermembuka websiteiRAN, di dalam menu home terdapat banyak fasilitas navigasi yang akan memudahkan user dalam melakukan kegiatan di dalam iRAN.

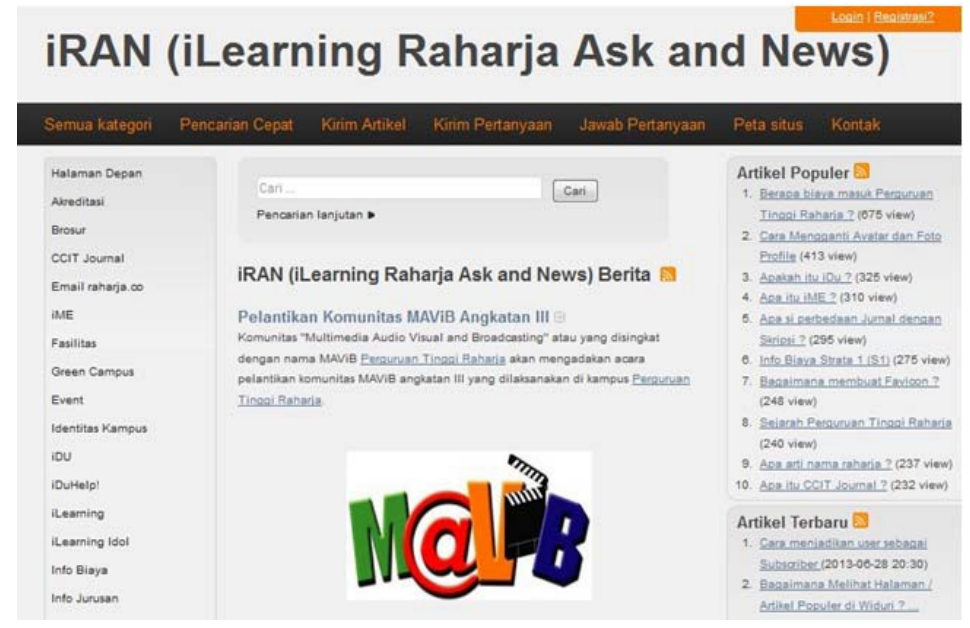

Gambar 9. Tampilan Home (Semua Kategori)

\section{Tampilan Menu Pencarian Cepat}

Menu pencarian cepat berfungsi saat pembaca ingin mencari artikel dengan cepat berdasarkan kata kunci yang diketikkan oleh pembaca, sehingga nanti akan muncul beberapa opsi artikel yang memiliki kata kunci yang mirip. 


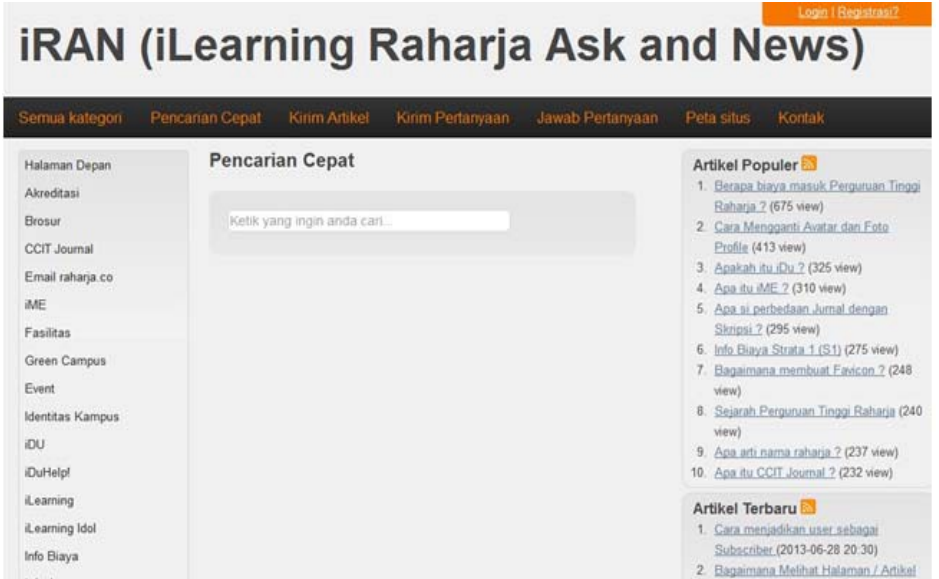

Gambar 10. Tampilan Menu Pencarian Cepat

4. Tampilan Menu Kirim Artikel

Menu kirim artikel merupakan fasilitas yang disediakan oleh iRAN dalam hal pemberian kontribusi bagi pribadi raharja untuk dapat berpatisipasi dalam mengisi kategori artikel yang tersedia di dalam iRAN.

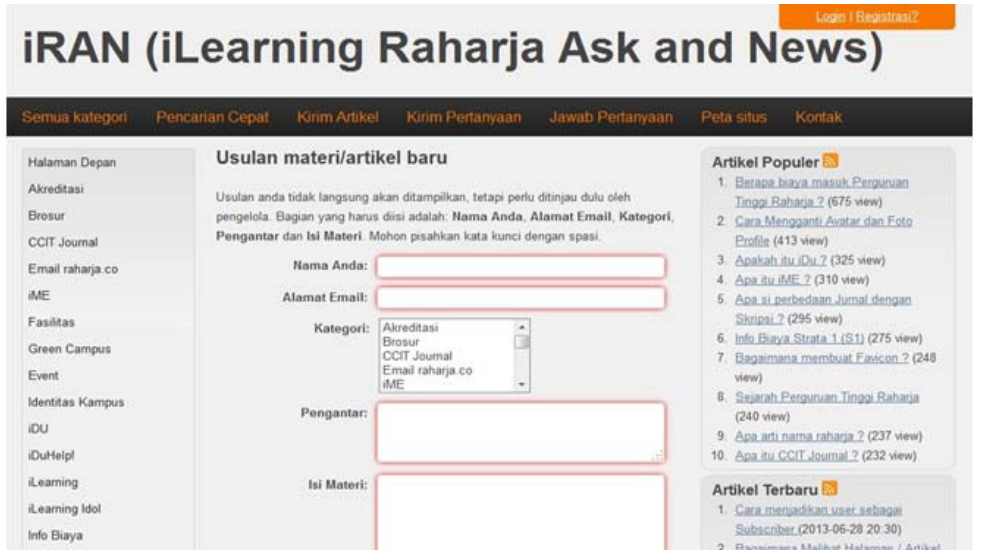

Gambar 11. Tampilan Menu Kirim Artikel

\section{Tampilan Menu Kirim Pertanyaan}

Menu ini berfungsi untuk memberikan kesempatan kepada pembaca untuk dapat mengirimkan pertanyaan jika artikel yang dicari tidak terdapat di iRAN. 


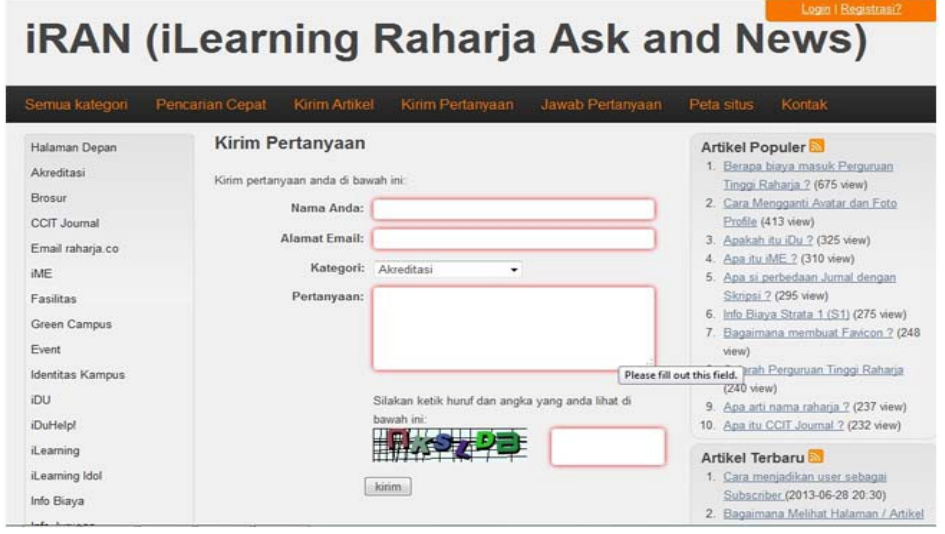

Gambar 12. Tampilan Menu Kirim Pertanyaan

6. Tampilan Menu Jawab Pertanyaan

Pada tampilan menu jawab pertanyaan berisi seluruh pertanyaan yang dikirim oleh pengunjung/ pembaca iRAN. Kemudian pada kolom pertanyaan kita dapat menjawab secara langsung pertanyaan tersebut.

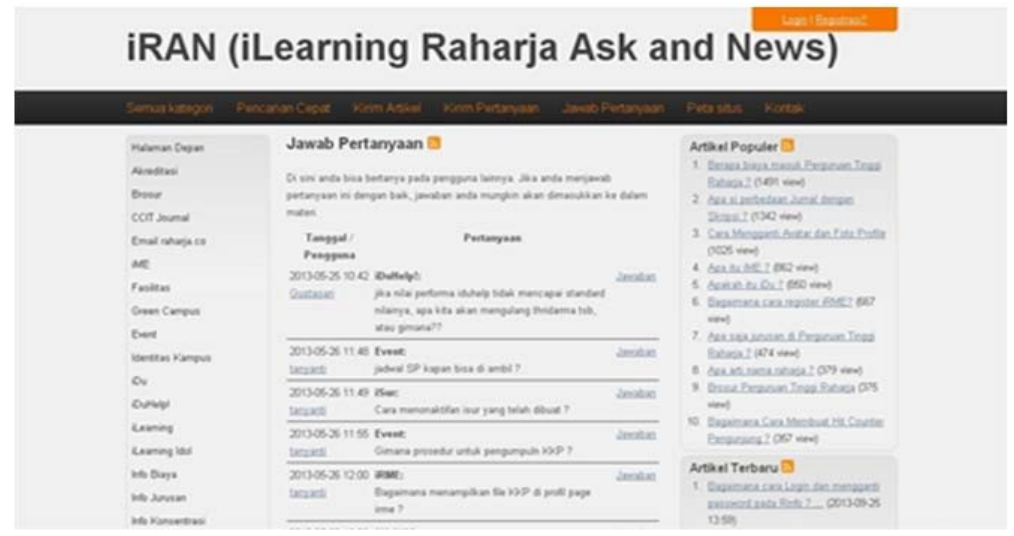

Gambar 13. Menu Jawab Pertanyaan

7. Tampilan Menu Kontak

Pada tampilan menu kontak ini kita dapat mengirimkan saran, kritikan, pendapat serta pujian kepada pengurus iRAN (admin) mengenai pelayanan serta tampilan yang disajikan. Pesan tersebut akan langsung terkirim ke email admin. 
Sehingga apapun yang menjadi kendala serta saran/pendapat ataupun kritikan dapat tersalurkan dengan baik.

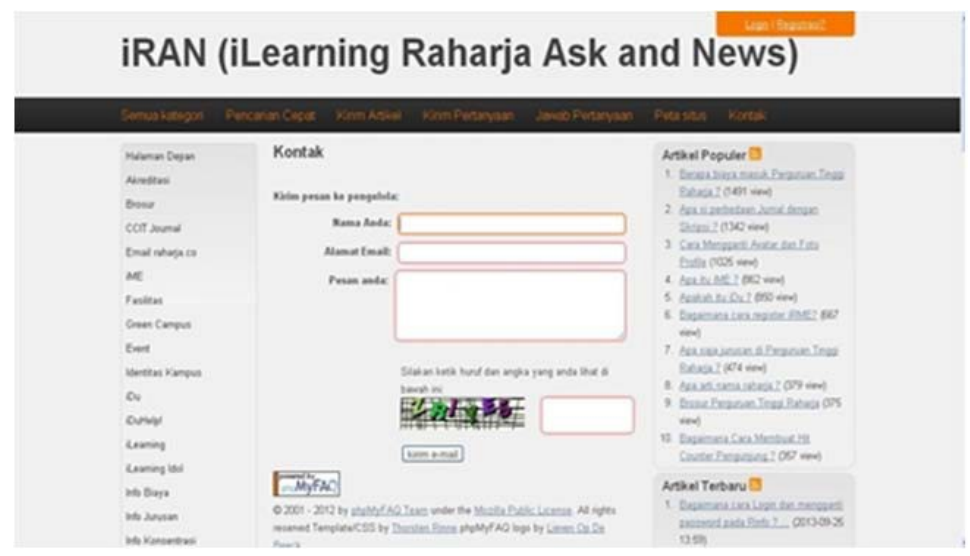

Gambar 14. Menu Kontak

8. Tampilan Form Login

Pada form login, user diwajibkan terlebih dahulu untuk memasukkan user dan Password agar dapat masuk ke dalam aplikasi dan dapat menjalankannya. Hal ini bertujuan untuk membatasi dalam pemakai yang mengakses aplikasi ini, sehingga hanya beberapa orang saja yang berhak dalam menjalankan aplikasi ini. Sehingga aman dari pemakaian-pemakaian lain yang tidak bertanggung jawab

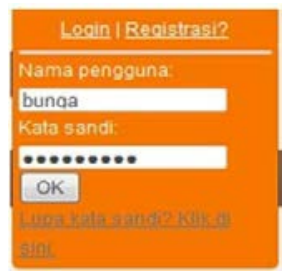

\section{Gambar 15. Tampilan Form Login}

\section{Tampilan Menu Admin}

Tampilan ini berisi fitur yang dapat digunakan oleh user dalam mengendalikan hak akses yang telah dimilikinya, selain itu juga didalammenu admin terdapat informasi dari aktivitas sistem iRan dimana kita bisa melihat statistis artikel serta kunjungan. 


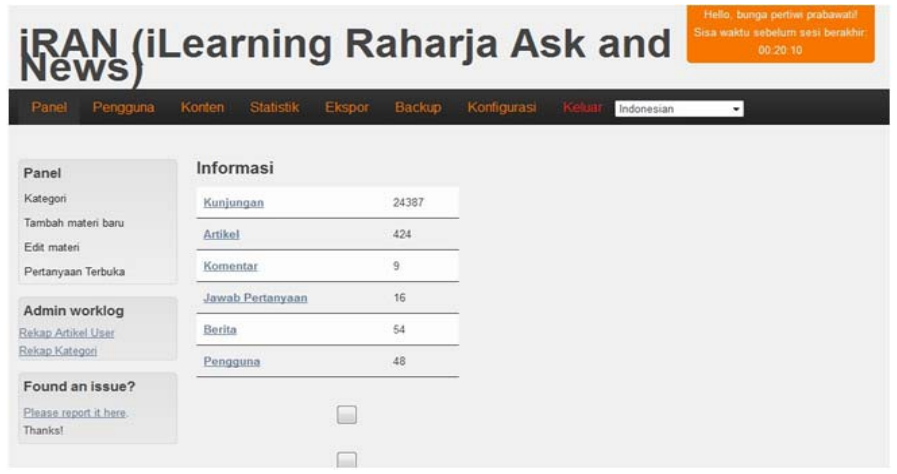

Gambar 16. Tampilan Menu Admin

B. Analisa Hasil

\section{Sebelum adanya iRAN}

\subsection{Tampilan Green Documentation}

Sistem yang berjalan perihal media pendokumentasian pada Peguruan Tinggi Raharja saat ini yaitu Green Documentation. Namun masih dikatakan bahwa sistem tersebut belum optimal. Hal tersebut dikarenakan pendataan yang masih manual dan tidak menyeluruh (tidak update), sehingga menyebabkan kesulitan dalam proses pencarian data karena tidak tersimpan dalam database yang baik. Seperti pada gambarberikut ini :

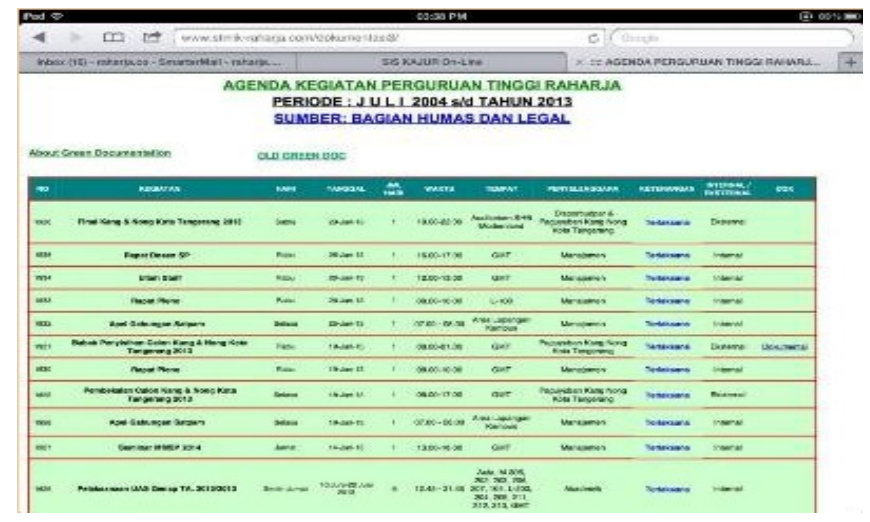

Gambar 17. Halaman Green Documentation 
Sistem iRAN dapat mengatasi masalah seputar media penyimpanan dokumentasi terutama dokumentasi kegiatan kampus. Hal ini dikarenakan perlunya suatu data dalam bentuk dokumentasi yang merekam semua kegiatan yang telah dilakukan. Maka Perguruan Tinggi Raharja yang bergerak di bidang pendidikan pun harus mencerminkan kampus IT yang up to date sehingga perlu dilakukan tahap penyesuaian pengembangan sistem penyimpanan dokumentasi berjalan ke dalam sistem yang dapat diakses secara online.

\section{Sesudah adanya iRAN}

Dengan diterapkannya media informasi kampus yang dapat diakses secara online terdapat suatu konsep dasar sistem informasi yang sangat penting dalam mendesain sebuah media informasi yang efektif. Oleh karena itu, suatu sistem informasi harus memiliki unsur-unsur yang terkandung dalam teori kualitas informasi. Adapun kualitas informasi (quality of information) tersebut diantaranya ditentukan oleh beberapa hal yaitu:

\subsection{Relevan}

Informasi yang diterima harus memberikan manfaat bagi pemakainya. Kadar relevancy informasi antara orang satu dengan yang lainnya berbeda-beda tergantung kebutuhan masing-masing pengguna informasi tersebut. How is the message used for problem solving (decision masking)?

Dalam hal ini, relevan dalam sistem iRan dapat diukur dari keberadaan berbagai macam tutorial mengenai kampus yang dapat dijadikan sebagai bahan untuk mencari informasi yang dibutuhkan oleh pengguna, terlihat dari koleksi artikel yang terdapat di iRan ada 400 artikel, pengguna dapat melakukan proses search beradasarkan kata kunci dari kebutuhan informasi yang diperlukan. Namun jika dalam mencari suatu informasi yang belum tersedia, pengguna tersebut dapat mengirimkan pertanyaan mengenai artikel yang dibutuhkan. Selanjutnya tugas admin akan menyediakan informasi tersebut. Dengan demikian relevancy dari sistem iRan dapat diukur dengan sejauh mana pengguna bisa menemukan informasi yang dibutuhkan dan sejauh mana pengguna tidak menemukan informasi tersebut melalui kirim pertanyaan yang terdapat di iRan.

\subsection{Akurat (Accurate)}


Informasi harus bebas dari kesalahan-kesalahan. Selain itu, informasi yang didapatkan tidak boleh bias atau menyesatkan bagi penggunanya serta harus dapat mencerminkan dengan jelas maksud dari informasi tersebut. Ketidak - akuratan data terjadi karena sumber dari informasi tersebut mengalami gangguan dalam penyampaiannya hal tersebut terjadi karena dilakukan secara sengaja maupun tidak sehingga menyebabkan data asli tersebut berubah atau rusak.

Sistem informasi memang harus memiliki tingkat kualitas informasi yang akurat dimana dalamunsurini sistem iRanmemiliki informasi yang cukup akurat. Berdasarkan artikel yang terkumpul merupakan artikel yang dibuat langsung oleh PIC dari masingmasing divisi. Misalnya saja di dalam iRan terdapat TPi(Ten Pilar iLearning) yang menyediakan kumpulan artikel penggunaan $\mathrm{TPi}$, sumber data yang diperoleh langsung dari PIC (Person In Charge) maksudnya PIC yaitu penanggung jawab dari project TPi, sehingga artikel yang tersimpan di iRan merupakan artikel yang akurat karena ada penanggung jawab dari si pembuat artikel.

\subsection{Tepat waktu (TimeLines)}

Informasi yang dibutuhkan oleh si pemakai dalam hal penyampaiannya tidak boleh terlambat (usang) karena informasi yang usang tidak mempunyai nilai yang baik dan kualitasnya pun menjadi buruk sehingga tidak berguna lagi. Jika informasi yang sudah usang tersebut digunakan sebagai dasar pengambilan keputusan maka akan berakibat fatal sehingga salah dalam pengambilan keputusan tersebut.

Dengan adanya layanan email news yang sudah tersedia di iRan, informasi yang disampaikan tidak akan terlambat karena waktu pengiriman sudah di setting dengan baik. Sehingga informasi yang dihasilkan juga berkualitas dari segi tepat waktu. Jika terjadi gangguan pada layanan news tersebut maka kualitas dari iRan akan terganggu.

\subsection{Ekonomis(Economy)}

What level of resources is needed to move information through the problemsolving cycle? Kualitas dari informasi yang digunakan dalam pengambilan keputusan juga bergantung pada nilai ekonomi yang terdapat didalamnya.

Dalam penggunaan media informasi online tidak mengeluarkan banyak biaya, berbeda dengan media cetak yang dulu diterapkan membutuhkan biaya besar dalam hal mencetaknya. Dengan adanya iRan pengeluaran untuk informasi lebih ekonomis. Sehingga sistem iRan dikatakan telah memenuhi syarat informasi yang berkualitas. 


\subsection{Efisien(Efficiency)}

What level of resources is required for each unit of information output? Kualitas dari informasi yang digunakan dalam pengambilan keputusan juga bergantung pada nilai efisien yang terdapat didalamnya.

Informasi yang di tampilkan di iRanmemilikinilai efesiensi dalam aspekwaktu. Sehingga berguna dalam proses pengambilan keputusan.

\subsection{Dapat dipercaya (Reliability)}

Informasi yang didapatkan oleh pemakai harus dapat dipercaya, hal ini menentukan terhadap kualitas informasi serta dalam hal pengambilan keputusan setiap tingkatanmanajemen.

Dari unsur-unsur penentu kualitas informasi diatas, kita dapat mengukur sendiri tingkat kualitas dari sistem informasi yang di tampilkan, apakah sudah sempurna atau belum. Menurut Gordon B. Davis nilai informasi dikatakan sempurna apabila perbedaan antara kebijakan optimal, tanpa informasi yang sempurna dan kebijakan optimal menggunakan informasi yang sempurna dapat dinyatakan dengan jelas. Oleh karena itu iRAN harus memiliki keenam elemen dari model kesuksesan sistem informasi [DeLone dan McLean, 1992] dan juga informasi yang dihasilkan harus memenuhi 6 unsur dari kualitas informasi.

Kelebihan sistem iRAN yaitu diantaranya mempermudahmelakukan pelayanan dengan sistematis guna meningkatkan kualitas pelayanan pada Perguruan Tinggi Raharja yang diberikan kepada seluruh mahasiswa khususnya dalam hal pemberian informasi di Perguruan Tinggi Raharja, melakukan analisa dan pengecekan terhadap sistem informasi yang telah ada, menghindari adanya informasi atau data yang telah usang ataupun data yang redundan yang terdapat dalam sistem dan membuat kualitas dari sistem menjadi buruk dikarenakan tidak dapat memberikan informasi yang relevan. Sedangkan manfaatnya yaitu teridentifikasinya kebutuhan-kebutuhan untuk meningkatkan Learning Management System pada Perguruan Tinggi Raharja, dalam pemenuhan kebutuhan informasi yang mudah diakses oleh setiap Pribadi Raharja.

\section{KESIMPULAN}

Berdasarkan penelitian yang telah dilakukan terhadap Penerapan Sistem iLearning Raharja Ask and News (iRAN) Dalam Mendukung Media Informasi Kampus pada Perguruan Tinggi Raharja dapat disimpulkan bahwaiRAN memenuhi 
standar kebutuhan informasi bagi seluruh Pribadi Raharja. Media informasi memiliki peranan penting dalam hal menyajikan informasi yang diperlukan oleh Pribadi Raharja. Media tersebut merupakan transformasi dari media cetak yang mampu menampilkan berita yang berisi kejadian, peristiwa serta informasi seputar kampus. iRAN merupakan media informasi kampus yang saat ini berjalan di Perguruan Tinggi Raharja. Tujuan dan manfaat penelitian dari sistem iRAN yaitu diantaranya mempermudah melakukan pelayanan dengan sistematis sesuai dengan sistem yang berjalan saat ini guna meningkatkan kualitas pelayanan pada Perguruan Tinggi Raharja serta teridentifikasinya kebutuhan-kebutuhan untuk meningkatkan Learning Management System pada Perguruan Tinggi Raharja, dalam pemenuhan kebutuhan informasi yang mudah diakses oleh setiap Pribadi Raharja.

\section{DAFTAR PUSTAKA}

[1] Fahme Dabaj,Agah Gumus. 2012. “The Mathematical Relationship Between The Lead And Body Lenghts, And The Degree Of Satisfation Attained From The Both Sections Of The News Articles Published In Newspapers: Case Study;Tuskish Daily Online Newspapers ”. ICCMTD. Istanbul - Turkey : Eastern Mediterranean University.

[2] Padmini Patwardhan, Jin Yang. 2003. “ Internet Dependency Relations And Online Consumer Behavior: A Media System Depedency Theory Perspective On Why People Shop, Chat And Read News Online”. Journal Of Interactive Advertising Vol 3 No 2. American : Academy Of Advertising.

[3] Klaus Schonbach, Ester De Waal, Edmund Lauf. 2005. “ Online And Print Newspapers: Their Impact On The Extent Of The Perceived Public Agenda “. European Journal Of Communication.

[4] Mark Deuze. 2003. “ The Web and Its Journalisms: Considering The Consequences Of Different Types Of Newsmedia Online “. New Media \& Society Vol5(2). Ascor, The Netherlands.

[5] W. H. DeLone, E. R. McLean. “ The DeLone and McLean Model of Information Systems Success : A-Ten-Year Update”. Journal Of Management Information System, Vol. 19 No. 4. www.proquest.com, diunduh 1 Maret 2008.

[6] Gordon B. Davis. 1995. “ Sistem Informasi Manajemen “. Jakarta : PT. Pustaka Binama Pressindo, hal. 27. 
[7] R. Untung, Y. Muhamad, R. Eva. 2012. "Perancangan Aplikasi iLearning Majalah Online Dengan Menggunakan iOS Programming Pada Perguruan Tinggi”. CCIT Journal Perguruan Tinggi Raharja: Indonesia.

[8] Murad. F. D, K. Nia, A. Agus. 2013. “Aplikasi Intelligence Website Untuk Penunjang Laporan Paud Pada Himpaudi Kota Tangerang “. CCIT Journal Vol.7 No. 1 Perguruan Tinggi Raharja : Indonesia.

[9] Djamarah. Pengetian Media. http://wawan-junaidi.blogspot.com/2012/01/ pengertian-media.html . (Tanggal akses 14 November 2013)

[10] Rahardja, Untung. Blog pribadi berjudul “ iLearning Start From Here ! “, iLearning Media (iMe). (Tanggal akses 8 Febuari 2013).

[11] Supriyani, Nofia. 2013. ” Perancangan Multimedia Audio Gallery iLearning Community and Services (MAGICS) Dalam Mendukung Sistem Pendokumentasian Digital Pada Perguruan Tinggi Raharja “. Laporan skripsi. Perguruan Tinggi Raharja-Indonesia. 